\title{
Chinese Urban Households' Security Market Participation: Does Investment Knowledge and Having a Long-term Plan Help?
}

\section{Postprint.}

For published article see:

Yao, R. \& Xu, Y. (2015). Chinese urban households' security market participation: Does investment knowledge and having a long-term plan help? Journal of Family and Economic Issues, 36(3), 328-339.

\begin{abstract}
Investment in the securities markets is vital to households' wealth accumulation and financial security. Using data from the 2008 Survey of Chinese Consumer Finance and Investor Education, we found that self-assessed investment knowledge and having a long-term financial plan were positively associated with Chinese households' participation in the securities markets. The findings provide insight into the long-term financial security of Chinese households. Given the growing middle class and the rapid development of the financial markets in China, the Chinese financial planning industry is likely to grow substantially in the coming years.
\end{abstract}

Keywords: China, financial capability, financial planning, investment decisions 


\section{Introduction}

Since 2002, the number of financial professionals has more than doubled worldwide (Financial Planning Standards Board (FPSB), n.d.). In 2013 alone, the number of Certified Financial Planners $\left(\mathrm{CFP}^{\circledR}\right)$ increased by almost $3.8 \%$, from 147,822 at year-end 2012 to 153,376 at year-end 2013 . According to the FPSB, one of the countries experiencing the greatest growth (second only to the US) was the People's Republic of China. This growing trend in China is likely to continue for a number of reasons (Larsen 2011). First, China's financial markets, while still underdeveloped, are expanding rapidly as a result of the liberation of China's financial systems. New financial institutions, products and services, especially in the securities markets, have become widely available to households (Didier and Schmukler 2014; Ledgerwood et al. 2013; Sharpe et al. 2012; Tam 2013). Second, as incomes and wealth rise, China's emerging middle class is increasingly demanding new, more complex financial offerings (e.g., Bruce et al. 2011; Farrell et al. 2006; Davies et al. 2011; Qin and Ren 2008). Third, more financial responsibilities have been passed to Chinese households due to recent economic and financial reforms in China (e.g., Liao et al. 2010; Didier and Schmukler 2014). Individuals now face greater employment uncertainty (Chamon and Prasad 2010; Meng 2003), as well as rapidly increasing costs of health care, housing, and education (Chamon and Prasad 2010; Qin 2003).

It is well established in the economic literature that investment behavior directly affects household wealth accumulation (e.g., Keister 2000). It is important that individuals and households formulate a long-term financial plan and acquire the necessary knowledge and skills to make wise investment decisions. Some individuals choose to increase their financial competency on their own. Others seek assistance from financial professionals with the appropriate levels of education and technical skills (Robb et al. 2012). In either case, research has found that those who had a financial plan were likely to accumulate more wealth by retirement than those who did not (e.g., Ameriks et al. 2003; Lusardi and Mitchell 2007). Having a financial plan and participating in the securities markets is particularly important right now for Chinese households as the financial planning industry and the securities markets are rapidly growing. 
A considerable body of research has examined financial planning and investment behaviors, especially for households in developed countries such as the US and Australia (e.g., Brandon and Welch 2009; Robb et al. 2012). Yet, very little was known about financial planning and investment behaviors in developing countries and emerging markets such as China, especially at the household level. (e.g., Brandon and Welch 2009; Claessens and Glaessner 1999). A small body of research has investigated the asset position and/or security holdings of Chinese households (e.g., Gan et al. 2014; He et al. 2009; Li et al. 2011; Liao et al. 2010; Lu and Gu 2009; Wang and Tian 2012). These studies, though, only examined the effects that basic demographics (such as age, education, income, and wealth) had on security ownership. The literature on this topic, while growing, is still scant. One important reason for the lack of research on this topic has been the limited availability of micro-level data on the finances of Chinese households.

Our study is the first to our knowledge to examine the role that having a long-term financial plan plays within the context of Chinese households' decision to hold different types of securities. This study uses data taken from the 2008 Survey of Chinese Consumer Finance and Investor Education, one of the first nationally representative surveys in China to provide detailed information on households' finances such as the types of securities held. The survey also uniquely included information about households' ownership of a long-term financial plan and their self-assessed investment knowledge. Our paper contributes to the literature in that it investigates whether having a long-term financial plan and the appropriate investment knowledge were associated with Chinese households' decisions to participate in the securities markets and invest in specific types of securities.

As previously mentioned, prior research has found a positive link between financial planning and wealth accumulation. This body of research has focused primarily on the impact that financial planning has had on US households' savings and investment decisions. Ameriks et al. (2003) used US data on TIAA-CREF participants and found that the line of causation likely runs from financial planning to wealth accumulation. Differences in the propensity to plan were positively and significantly associated with differences in wealth accumulation. Lusardi (1999) used the Health and Retirement Study (HRS) 
and found that US households who had given "little or no" thought to retirement had significantly lower levels of financial wealth than those who had given more thought. Lusardi (2001) also found that planning led to increases in wealth holdings in high return assets such as stocks, a potentially important contributor to long-term wealth accumulation.

Past research also has found a link between financial literacy and participation in the securities markets - again, the work has primarily focused on US households. Van Rooij et al. (2011) found those with low literacy on compound interest, inflation, bond price, etc. were significantly less likely to invest in stocks. Those who understood compound interest were also more likely to have planned for retirement (Lusardi and Mitchell 2007). Additional work by Kimball and Shunway (2010) found that survey respondents who scored higher on financial quizzes were more likely to choose a portfolio consistent with what economists would recommend.

The results from our empirical analysis suggest that Chinese urban households that reported having a long-term financial plan and possessing better investment knowledge were significantly more likely to participate in the securities markets. These findings have important implications for China's emerging financial planning industry. As China's financial markets become more liberalized due to changes in government policies and the series of economic reforms, households will have greater access to a wider and more complex array of new financial services and products. Those who actively seek out financial planning services and have a long-term financial plan are likely to reap the benefits that the profession has to offer, resulting in higher wealth accumulation and greater long-term financial security.

\section{Conceptual Framework}

To put this study into economic context, consider first the life-cycle approach to examining households' decisions related to saving, investment and wealth accumulation. In this traditional economic framework, key determinants have included age, household structure, lifetime earnings, and preference parameters such as the discount rate and bequest motive. However, more recent research in line with behavioral economics and finance has suggested that other factors (i.e., psychological, social, cognitive, and emotional factors) were significantly related to households' investment decisions and wealth 
accumulation. These factors were not explicitly included in the traditional life-cycle model (e.g., Ameriks et al. 2003), yet they played an important role in the Behavioral Life-cycle Hypothesis (Shefrin and Thaler 1988).

In particular, Van Rooij et al. (2011) pointed out that traditional socio-economic controls and lifecycle assumptions had not been adequately able to explain the puzzle as to why so many households did not participate in the securities market, especially the stock market (Campbell 2006). They highlighted behavioral research that studied a number of other, non-traditional factors such as the influence of: trust and culture; neighbors and peers; limited numeracy; intelligence quotient and cognitive ability; and lack of asset awareness. Lusardi et al. 2011, 2013 and Van Rooij et al. 2011 studied how financial literacy and capability affected households' savings and investment decisions over the life cycle. In their model, households could gradually build their levels of financial knowledge and capability so as to enhance the long-run expected return on their investments such as stocks and mutual funds. Such improvements in knowledge and capability were a human capital investment that involved time and effort to acquire information and experience as well as money to pay for financial services and products.

In line with previous behavioral economic reasoning (e.g., Lusardi et al. 2011, 2013; Van Rooij et al. 2011), we hypothesize that a household's self-assessed financial knowledge is likely to positively affect the decision to invest in securities. In particular, we hypothesized that this effect is likely to be stronger for more complex investment decisions such as investing in stocks and mutual funds versus more risk-free investment instruments such as government bonds. This was because that stocks and mutual funds require a more sophisticated level of financial understanding to assess the short- and long-run risks and returns associated with these types of products than say government bonds.

Similar to Ameriks et al. (2003), Lusardi (1999) and Lusardi (2001), who found that having a financial plan was positively related to security market participation, we also hypothesized that having a long-term financial plan plays a similar role in positively affecting the decision to invest in securities. We also took this one step further and hypothesized that having some type of financial plan, and thus more experience in formulating and executing a financial plan, is likely to affect the types of securities held, 
with more financial experience being associated with a greater likelihood of investing in more sophisticated investment products such as stocks and mutual funds with higher risks but also higher rates of return.

Finally, while much of the behavioral economic research has focused on US households, we expected these relationships between self-assessed financial knowledge, planning, and participation in the securities markets to hold for our sample of Chinese households. Since investing in the securities market was a relatively new and important financial option for Chinese households to build wealth over the long run, the relationship could be even stronger for the Chinese households.

\section{Empirical Models}

To empirically test our hypotheses, a series of logistic regressions were estimated to determine whether Chinese urban households that were more knowledgeable and more actively engaged in the financial planning process were also more likely to participate in the securities markets. For the first logistic regression, the dependent variable was whether the household held at least one security. A second set of logistic regressions were estimated for each of the three types of securities held - stocks, mutual funds, and government bonds. For each of these models, the dependent variable was equal to 1 if the household held the security and 0 otherwise. ${ }^{1}$

Independent variables were selected based on prior economic and behavioral economic research related to household saving and investment decisions (e.g., Benzoni et al. 2007; Bertaut 1998; Bertaut and Starr-McCluer 2000; Chamon and Prasad 2010; Cocco et al. 2005; He et al. 2009; Heaton and Lucas 2000; Lu and Gu 2009; Meng 2003; Powell and Ansic 1997; Qin 2003; Sundén and Surette 1998). The key variables of interest in the models were whether the household had a long-term financial plan, whether the household had at least some understanding of the financial planning methods currently available as well as of the risk and return associated with various financial products. The models also

\footnotetext{
${ }^{1}$ Ideally, it would be informative to know the specific amounts held in each type of security. However, financial information in the SCCFIE was collected in the form of categorical variables and so it was not possible to determine the specific amounts held.
} 
controlled for sources of financial planning information, factors related to the financial position of the household, as well as demographic variables.

\section{Data}

To estimate these models, data were taken from the 2008 Survey of Chinese Consumer Finance and Investor Education (SCCFIE). The survey was designed and conducted by the China Center for Financial Research at Tsinghua University in Beijing, China and sponsored by Citi Foundation. It was among the first nationally representative surveys in China to provide detailed and comprehensive information on household demographics, financial planning practices and attitudes, balance sheet items, savings practices and attitudes, household income and expenses, debt behavior and attitudes, retirement, and estate planning. In anticipation of some cultural resistance from the respondents in providing private information someone they did not know, most information in the SCCFIE was collected in the form of categorical variables. $^{2}$

In the 2008 SCCFIE, urban households were randomly selected from each of the 15 cities located in East, Middle, West and Northeast parts of China, representing urban areas in China including three administrative divisions: (a) municipalities directly under the Central Government (first level), (b) cities at the sub-provincial level (second level), and (c) cities at the prefecture level (third level). ${ }^{3}$ Based on the population distribution in each district in these cities, households were randomly selected from each district. In this survey, a household was defined as a single individual or a core couple and all other individuals living under one roof who were financially interdependent. The respondent in each household was the person most knowledgeable about the household finances and who made the household financial decisions. Face-to-face interviews were conducted with a total of 2,095 households. Only 16 households $(0.6 \%$ of the total sample) provided missing values in the variables used in the analyses. These households were excluded from the study. As a result, the total sample size was 2,079.

\footnotetext{
${ }^{2}$ For a detailed description of the data, see Liao et al. (2010).

${ }^{3}$ Note that the geographical information was not included in our dataset.
} 
With regard to the key variables used in this study, the SCCFIE collected information on Chinese households' decision to participate in the securities market. Specifically, households were asked about their decision to hold stocks, mutual funds, and/or government bonds. Uniquely, the SCCFIE is one of the few, if not only, surveys to also collect information on Chinese households' financial planning practices and knowledge, which enables one to investigate whether financial planning and knowledge are associated with the decision to participate in the securities markets, as well as the decision to invest in specific types of securities.

Central to the financial planning process is whether a household has a financial plan. Within the SCCFIE, there was a section called "Family Financial Planning." Households were asked in this section "Do you have a long-term financial plan?" For the purposes of this study, this question was used as the key control for household's financial planning behavior. Within this section of the survey, households were also asked about their level of understanding of two core financial planning concepts: (1) "To what extent, do you understand the types of financial planning methods currently available?" (2) "To what extent, do you understand the risk and return associated with various financial products?" These two questions were used in our study to measure a household's self-assessed financial planning knowledge. ${ }^{4}$ As discussed in many prior studies (e.g. Allgood and Walstad 2013; Babiarz and Robb 2014; Robb and Woodyard 2011; Xiao et al. 2011), the self-assessed knowledge level is subjective and could differ from the objective knowledge level assessed by financial knowledge quizzes. Self-assessed knowledge likely reflects the respondent's confidence, which, in turn, can lead to a higher likelihood to participate in the securities markets.

The SCCFIE also collected information for sources of financial planning information, including relatives and friends, radio and TV, newspapers, Internet, and financial institutions. Other independent variables were more traditional in nature and accounted for factors related to the financial position of the

\footnotetext{
${ }^{4}$ Hilgert et al. (2003) explored the link between financial knowledge and behavior, focusing on four broad categories of financial practices: cash-flow management, credit management, savings, and investments. They found financial knowledge in specific areas to be positively correlated with financial practices in those areas. We also expect to find a positive relationship such that greater financial planning understanding is likely to result in more sophisticated and complex financial investments.
} 
household such as income and wealth in terms of the value of the household's residential properties.

Demographics such as education, age, gender, and marital status were also included.

\section{Descriptive Analyses}

\section{Security Holdings and Financial Planning and Self-assessed Investment Knowledge}

Table 1 presents descriptive findings for the key variables of interest. Specifically, it shows the relationship between Chinese households' security holdings and their financial planning and knowledge. The first column of Table 1 shows the types of securities held for the entire sample. Over two-thirds of Chinese urban households (67.7\%) reported that they did not hold any type of security, where securities were defined as stocks, mutual funds, and/or government bonds. Of those who reported holding some type of security, stocks and mutual funds were found to be the most common type held. On average, $14.0 \%$ of all households held only stocks, $4.0 \%$ held only mutual funds, and $6.5 \%$ held a combination of both stocks and mutual funds. The concentration, though, was found to be primarily in stocks.

Government bonds were the least likely type of security to be held by Chinese urban households, where $2.0 \%$ reported holding only government bonds and only another $6.0 \%$ reported holding government bonds with some combination of stocks and/or mutual funds.

\section{[Insert Table 1 about here]}

The remaining columns in Table 1 examine financial planning and self-assessed knowledge for households with different types of security holdings. Overall, 55.9\% of Chinese households reported having a long-term financial plan, $63.7 \%$ reported having at least some understanding of financial planning methods and $49.4 \%$ reported having at least some understanding of the risk and return associated with various financial products. Table 1 also shows that holding at least one type of security, and especially a combination of securities, was associated with having a long-term financial plan, at least some understanding of current financial planning methods, and at least some understanding of the risk 
and return associated with various financial products. For instance, $73.6 \%$ of households that held only stocks reported having a long-term financial plan compared to only $55.9 \%$ of the entire sample.

Moreover, when the households' stock holdings were combined with mutual funds and/or government bonds, the households were more likely to report having a long-term financial plan than the average household.

With regard to self-assessed financial planning knowledge, Table 1 also shows that in general $63.7 \%$ of all households reported having at least some understanding of current financial planning methods. Those holding at least some type of security were more likely to have at least some understanding, especially compared to households on average. For example, among those holding stocks and mutual funds, the percentage was at least $82.1 \%$ compared to $63.7 \%$ for all households. With regard to risk and return, only $49.4 \%$ of all households reported having at least some understanding of the risk and return associated with various financial products. However, the percentage was found to be considerably higher for those holding a combination of securities (e.g., $91.9 \%$ of those holding all three securities compared to only $60.0 \%$ of those holding government bonds only). Overall, these findings suggest that those holding securities may be more likely to be engaged and knowledgeable about financial planning to begin with. The regression analysis will empirically test these relationships holding several factors constant.

\section{Summary Statistics for All Key Variables}

Table 2 presents the summary statistics for the variables used in the regression analysis. The first column of Table 2 reports the descriptive findings for the full sample. Besides the key variables of interest (i.e., financial planning and knowledge), households were asked where they were acquiring their financial planning information. Respondents were given five choices to select from and they could identify multiple sources. The most frequently identified sources were relatives and friends (59.2\%), radio and TV (47.7\%), newspapers, magazines, and books (45.7\%), followed by the Internet (37.9\%). Only one third of households utilized financial institutions (33.4\%), such as banks and mutual fund companies, to acquire financial planning information. 


\section{[Insert Table 2 about here]}

The first column of Table 2 also includes information on household income, wealth, and general demographics for the entire sample. Over one-third of the households were in the first (bottom) quartile of the income distribution (37.4\%), while about one-quarter was in the fourth (top) quartile (24.5\%). The vast majority reported owning some type of residential property $(85.0 \%)$, with about half of the households (50.3\%) reporting residential property valued between 100,000 Yuan and 500,000 Yuan. ${ }^{5}$ The remaining residential property values were split about equally above and below this range. In terms of education, $43.8 \%$ households were headed by respondents who had a high school education and $37.6 \%$ by respondents with at least some college education. The majority of households were headed by respondents who were 41 years old or older (52.9\%). Over half of the respondents were female (55.1\%) and over three-quarters were married (77.2\%).

The remaining columns in Table 2 present the descriptive findings according to whether the household held some type of security and the specific type of security held. The findings for financial planning and knowledge confirmed the relationships found in Table 1 . Only $32.3 \%$ the households reported holding some type of security. Those holding securities were considerably more likely to have a long-term financial plan, with $77.8 \%$ of those holding securities having a plan compared to $45.5 \%$ of those not holding securities. Similarly, $85.4 \%$ of those with securities reported at least some understanding of the financial planning methods currently available, compared to only $53.2 \%$ of those who reported no understanding. The results for the second knowledge question were akin to those of the first $-84.7 \%$ of those with security holdings had at least some understanding of the risk and return associated with financial products, whereas only $32.7 \%$ of those without a plan reported some level of understanding. Moreover, the results were found to be similar across the different types of security

\footnotetext{
${ }^{5}$ At the time of the survey interview, the exchange rate was about 6.83 Chinese Yuan to 1 US dollar.
} 
holdings. Those who reported holding stocks, mutual funds, and/or government bonds were more likely to have a long-term financial plan, have at least some understanding of current financial planning methods, and have at least some understanding of the risk and return associated with various financial products.

A few other findings to note from Table 2 were related to differences in income and wealth according to whether the household was holding securities or not. These findings, though, are perhaps not surprising. Among households holding securities, about half were in the highest income quartile (47.0\%), compared to only about a quarter of the entire sample (24.5\%). Those holding securities were also more likely to have residential property values above 500,000 Yuan.

Overall, these initial statistics suggested that for Chinese urban households a relationship was likely to exist between financial planning practices, self-assessed investment knowledge, and participation in the securities markets. From these initial findings, we expected holding securities to be positively correlated with having a long-term financial plan as well as being more knowledgeable about financial planning methods and the risk and returns associated with various financial products. In the sections that followed, we tested whether these hypotheses and our descriptive findings could be supported by the regression analysis, which controlled simultaneously for the key factors presented in Table 2.

\section{Empirical Results}

Table 3 presents the coefficients and the odds ratios from the logistic models for security holdings. In general, the results supported the descriptive findings. The first column in Table 3 presents the results for the likelihood of holding at least one security. In general, financial planning practices were found to significantly predict security holdings. Compared with households who did not have a long-term financial plan, those who had a plan were 2.3 times as likely to hold securities. Compared to those who reported having no understanding of the financial planning methods currently available, those who reported at least some understanding were 1.4 times as likely to hold securities. Similarly, those who reported at least some understanding of the risk and return and associated with various financial products were 6.6 times as likely to hold securities as those who had no such understanding. In addition, sources 
of financial planning information were found to be significant predictors of security holdings. All else being equal, households whose sources for financial information were newspapers, magazines and/or books were $22.7 \%$ less likely to hold securities than those who did not use these sources for financial information. Those whose source of financial information came from the Internet were $46.2 \%$ more likely to hold securities than those who did not use Internet for such information. It is likely that people who sought information from traditional sources (e.g. books, magazines, newspapers, TV and radio) were more likely to be conservative and less likely to participate in the securities markets. Similarly, people who sought information from Internet were likely to be less conservative than those who did not, and were, therefore, more likely to participate in the securities markets.

\section{[Insert Table 3 about here]}

Not surprisingly, the likelihood of investing in securities significantly increased with household income. Compared with households in the first (lowest) income quartile, households in higher quartiles were significantly more likely to hold securities. The gap in the likelihood of holding securities widened as household income increased, as was evidenced by the odds ratio increasing from 2.1 for the third quartile to 4.2 for the fourth quartile. Value of residential property was also a key determinant. In particular, households with residential property values higher than 500,000 Yuan were 2.2 times as likely to hold some type of security compared to those who did not own any residential property. Education and age were found to positively affect the likelihood of investing in securities as well.

The remaining columns in Table 3 present the logistic models for the likelihood of holding stocks, mutual funds, and government bonds, respectively. It is important to note that the stocks, mutual funds and government bonds differ in terms of risks and, therefore, require different levels of financial sophistication. Individual stocks are often riskier than mutual funds because mutual funds are more diversified and professionally managed. Bonds are generally considered to be the least risky among the 
three because they are debt and not ownership and have significantly lower default risks than stocks. As such, investing in stock and mutual funds requires higher risk tolerance than investing in government bonds. There is a very organized and liquid secondary market for stocks to be traded. Mutual funds can be bought and redeemed from the fund companies easily. Investors in government bonds often hold them until the maturity date as the secondary market for bonds in China is still underdeveloped (Zhao 2012). As such, we expect financial planning and self-assessed financial knowledge to have different effects on holdings of different securities.

In these models, financial planning practices were again found to be strong predictors and for all three securities. Households who reported having a long-term financial plan were 2.0 times as likely to invest in stocks, 1.9 times as likely to invest in mutual funds, and 2.6 times as likely to invest in government bonds, compared to those who reported not having a long-term plan. Self-assessed financial knowledge, especially knowledge of the risk and return associated with various financial products, was positively associated with the likelihood of holding each type of security. Compared with households who reported no understanding of the risk and return associated with various financial products, those who reported some understanding were 7.6 times as likely to own stocks, 4.5 times as likely to own mutual funds, and 1.8 times as likely to own government bonds. Understanding of the financial planning methods currently available only increased the odds of having mutual funds by $63.4 \%$ but did not significantly affect the odds of holding stocks or government bonds.

While sources of financial planning information did not explain holdings in government bonds, they were correlated with investments in stocks and mutual funds. In particular, those who received information from the Internet were $48.0 \%$ more likely to invest in stocks than those who did not report the Internet as a source of information. However, those who received information from radio and TV were 28.4\% less likely to invest in mutual funds, and those who received information from newspaper, magazines, and books were $28.5 \%$ less likely, compared to those who did not report those information sources. As we stated before, those use Internet were less likely to be conservative and therefore more 
likely to invest in risky securities, whereas those receive information from traditional sources were likely to be conservative and avoid risky securities.

Similar to the results in the first column, income and wealth effects were also found for all three types of securities. Households in the third and fourth income quartiles were generally more likely to hold stocks, mutual funds, and government bonds. Those in the second quartile were $59.8 \%$ more likely to hold stocks, compared with households in the lowest quartile. Compared to households with no residential property, those with property values higher than 500,000 Yuan were 2.6 times as likely to invest in stocks.

Demographic variables also explained security holdings. Higher levels of education predicted greater likelihood of participation in the securities market. Compared with respondents who had less than a high school education, those who had a high school diploma and at least some college were more likely to own stocks and mutual funds. It is perhaps not surprising to note that Chinese urban households' investment decisions had a life-cycle effect. Compared with households headed by respondents who were less than 35 years old, those headed by respondents aged 41-50 were 59.1\% more likely to own stocks and $138.2 \%$ more likely to own government bonds, whereas those headed by respondents above 50 years old were 5.1 times as likely to own government bonds. This finding suggests that households were switching to more conservative investment choices (i.e., government bonds) as the household head approached retirement age. ${ }^{6}$

\section{Conclusion and Implications}

This study investigated how financial planning practices and self-assessed financial knowledge relates to households' participation in the securities markets, using detailed household survey data from China. The empirical findings showed that Chinese urban households with a long-term financial plan were significantly more likely than those without a plan to hold various types of securities such as stocks, mutual funds, and/or government bonds. The findings also showed that reporting certain understanding

\footnotetext{
${ }^{6}$ In China, the typical retirement age is 50 for women and 55 for men, except for government employees whose retirement age is 60 regardless of gender.
} 
of financial planning methods and investment risk and return explained a household's decision to hold securities. The present study contributes to the behavioral economics literature in that it incorporates financial planning and self-assessed financial knowledge as important factors for security investment decisions.

When interpreted in the context of Chinese financial market, the empirical results found in the present study provide important implications for Chinese household finance and the development of the financial planning industry. In recent years, China's financial markets have become more liberalized due to changes in government policies and the series of economic reforms. Now, more than ever before, households have greater access to a wider and more complex array of new financial services and products. Evidence presented in this study identifies particular groups of individuals who may be at a greater financial advantage: those who believed they were more knowledgeable and actively engaged in the financial planning process were also more likely to be engaged in the securities markets. Although security investment bears higher risks than savings, it also provides the potential for the participants to accumulate significant wealth.

According to the SCCFIE, only one-third of Chinese urban households participated in the securities markets in 2008 . This may be partially attributed to an inadequate understanding of financial planning information - the present study shows that one-third of Chinese urban households reported no understanding of the financial planning methods currently available and over half of them reported no understanding of the risk and return associated with various financial products. These results suggest a great opportunity for financial services professionals and financial educators to reach out to clients and the general public, inform them about financial planning methods, and educate them about the risks and returns of various financial products. As suggested by the survey, most households in the SCCFIE sample sought financial planning information from their friends and relatives, which may not be the best source of information when making financial decisions. Nevertheless, it is likely that friends and relatives were the most preferred source of information because they are perceived to be trustworthy. The 
implication of this result is that there is a great potential for further development of the financial planning industry in China.

Millions of Chinese urban households now have access to a wider and more complex array of new financial products and services. Without adequate understanding of financial planning methods and investment risk and return, it can be a challenge for these households to make optimal investment decisions to achieve their financial goals and accumulate wealth. Although the financial planning industry has expanded during recent years, further growth of the industry and its financial planning services could provide critical assistance in helping Chinese urban households improve their long-term financial security. One of the roles for financial advisors is to provide information to their clients about financial products and the market (Marsden et al. 2011). Based on our findings, potential directions for the Chinese financial planning industry development include: 1) information related to financial planning methods and characteristics of financial products (including risks and returns) need to be disseminated to the general public; 2) the channels of such information need to be trustworthy; and 3) the information needs to be understood by the general public.

This study is the first one to our knowledge that investigate the Chinese households' security market participation under a behavioral finance framework that accounts for financial planning and selfassessed financial knowledge. The primary focus is to study the association between those factors and security holdings without an attempt to infer any causality. We acknowledge the potential endogeneity and possible dual endogeneity between our dependent variables and some of our independent variables. For example, in our models we assume having a long-term financial plan is exogenous. Meanwhile, having a long-term financial plan could be dependent on a number of factors, including whether or not the household held securities. Both Ameriks et al. (2003) and Lusardi (2001) pointed out that it may be wealth that drives thinking about future financial planning rather than vice versa. However, the findings of Ameriks et al. (2003) suggested that the propensity to plan was associated with wealth accumulation in that financial planners save more. Unfortunately, most of the survey questions were asked in present tense, which prevented us from being able to discern with certainty the timing of which came first - the 
financial planning or the purchasing of the securities. Another limitation of the study is the absence of measures for other economic factors such time preference and risk reference and psychological factors such as personality and self-control (Xu et al. 2015). Future studies on Chinese households' security market participation should consider including these economic factors and addressing the potential endogeneity issue. 


\section{References}

Allgood, S., \& Walstad, W. (2013). Financial literacy and credit card behaviors: A cross-sectional analysis by age. Numeracy, 6(2), 3 .

Ameriks, J., Caplin, A., \& Leahy, J. (2003). Wealth accumulation and the propensity to plan. The Quarterly Journal of Economics, 118(3), 1007-1047. doi: 10.1162/00335530360698487.

Babiarz, P., \& Robb, C. A. (2014). Financial literacy and emergency saving. Journal of Family and Economic Issues, 35(1), 40-50.

Benzoni, L., Collin-Dufresne, P., \& Goldstein, R. S. (2007). Portfolio choice over the life cycle when the stock and labor markets are cointegrated. The Journal of Finance, 62(5), 2123-2167. doi: $10.1111 / \mathrm{j} .1540-6261.2007 .01271 . x$.

Bertaut, C. C. (1998). Stockholding behavior of US households: Evidence from the 1983-1989 Survey of Consumer Finances. Review of Economics and Statistics, 80(2), 263-275. doi:10.1162/003465398557500.

Bertaut, C., \& Starr-McCluer, M. (2000). Household portfolios in the United States. FEDS Working Paper, No. 2000-26. Washington, DC: Board of Governors of the Federal Reserve System. doi:10.2139/ssrn.234154.

Brandon Jr, E. D., \& Welch, H. O. (2009). The history of financial planning: The transformation of financial services. Hoboken, New Jersey: John Wiley \& Sons Inc.

Bruce, K., Ahmed, A., \& Huntly, H. (2011). An approach to understanding the professionalism of financial planners. Journal of Business Systems, Governance and Ethics, 6(3), 1. doi: $10.15209 /$ jbsge.v6i3.205.

Campbell, J. (2006). Household finance. Journal of Finance, 61, 1553-1604. doi: 10.1111/j.15406261.2006.00883.x.

Chamon, M. D., \& Prasad, E. S. (2010). Why are saving rates of urban households in China rising? American Economic Journal: Macroeconomics, 2(1), 93-130. doi: 10.1257/mac.2.1.93.

Claessens, S., \& Glaessner, T. C. (1999). Internationalization of financial services in Asia (No. 1911). Washington, DC: World Bank, Poverty Reduction and Economic Management Network, Economic Policy Division. doi: 10.1596/1813-9450-1911.

Cocco, J. F., Gomes, F. J., \& Maenhout, P. J. (2005). Consumption and portfolio choice over the life cycle. Review of Financial Studies, 18(2), 491-533. doi: 10.1093/rfs/hhi017.

Davies, J. B., Sandström, S., Shorrocks, A., \& Wolff, E. N. (2011). The Level and distribution of global household wealth. The Economic Journal, 121(551), 223-254. doi: 10.1111/j.14680297.2010.02391.x.

Didier, T., \& Schmukler, S. L. (2014). Financial development in Asia: beyond aggregate indicators. World Bank Policy Research Working Paper, No. 6761. Washington, DC: The World Bank. doi:10.1596/1813-9450-6761.

Farrell, D., Gersch, U. A., \& Stephenson, E. (2006). The value of China's emerging middle class. McKinsey Quarterly, 2(1), 60-69.

Financial Planning Standards Board. (n.d.). CFP Professionals Infographic. Retrieved from https://www.fpsb.org/index.php.

Gan, L., Yin, Z., Jia, N., Xu, S., Ma S., \& Zheng, L. (2014). Data you need to know about China: Research report of China Household Finance Survey 2012. Berlin, Germany: Springer. doi: 10.1007/978-3-642-38151-5.

He, X., Shi, W., \& Zhou, K. (2009). Background risk and investors' participation in risky financial assets. Economic Research Journal, 12, 119-130. [in Chinese]

Heaton, J., \& Lucas, D. (2000). Portfolio choice and asset prices: The importance of entrepreneurial risk. The Journal of Finance, 55(3), 1163-1198. doi: 10.1111/0022-1082.00244.

Hilgert, M.A., J. M. Hogarth, \& Beverly, S. (2003). Household financial management: The connection between knowledge and behavior. Federal Reserve Bulletin, 89, 309-322. 
Keister, L. A. (2000). Race and wealth inequality: The impact of racial differences in asset ownership on the distribution of household wealth. Social Science Research, 29(4), 477-502. doi: $10.1006 /$ ssre.2000.0677.

Kimball, M., \& Shumway, T. (2010). Investor sophistication and the participation, home bias, diversification, and employer stock puzzles. Unpublished Manuscript, University of Michigan. doi: $10.2139 /$ ssrn. 1572866 .

Larsen, C. (2011, June 1). FPA in China: How the Chinese invest now and for retirement. ThinkAdvisor. Retrieved from http://www.thinkadvisor.com/2011/06/01/fpa-in-china-how-the-chinese-investnow-and-for-re?page_all=1

Ledgerwood, J., Earne, J., \& Nelson, C. (Eds.). (2013). The New Microfinance Handbook: A Financial Market System Perspective. Washington, DC: World Bank Publications. doi: 10.1596/978-08213-8927-0.

Li, X., Xiao, B.,Yu, H., \& Song, J. (2011). Survey of household finance. Journal of Management Sciences in China, 14(4), 74-85. [in Chinese]

Liao, L., Huang, N., \& Yao, R. (2010). Family finances in urban China: Evidence from a national survey. Journal of Family and Economic Issues, 31(3), 259-279. doi: 10.1007/s10834-010-9218-z.

$\mathrm{Lu}, \mathrm{J} .$, \& Gu, J. (2009). Analysis on the influencing factors in household financial portfolio selection Evidence From Nanjing, Jiangsu province. Journal of Financial Development Research, 10, 25 29. [in Chinese]

Lusardi, A. (1999). Information, expectations, and savings for retirement. In H. J. Aaron (Ed.), Behavioral Dimensions of Retirement Economics (pp. 81-115). Washington, DC: Brookings Institution Press.

Lusardi, A. (2001). Explaining why so many people do not save. Center for Retirement Research at Boston College, Working Paper No. 2001-05. Chestnut Hill, MA: Center for Retirement Research at Boston College. doi:10.2139/ssrn.285978.

Lusardi, A., Michaud, P. C., \& Mitchell, O. S. (2013). Optimal financial knowledge and wealth inequality (No. w18669). National Bureau of Economic Research. doi: 10.3386/w18669.

Lusardi, A., Michaud, P. C., \& Mitchell, O. S. (2011). Optimal financial literacy and saving for retirement. doi: 10.2139/ssrn.1978960.

Lusardi, A., \& Mitchell, O. S. (2007). Baby boomer retirement security: The roles of planning, financial literacy, and housing wealth. Journal of Monetary Economics, 54(1), 205-224. doi:10.1016/j.jmoneco.2006.12.001.

Marsden, M., Zick, C. D., \& Mayer, R. N. (2011). The value of seeking financial advice. Journal of Family and Economic Issues, 32(4), 625-643. doi: 10.1007/s10834-011-9258-z.

Meng, X. (2003). Unemployment, consumption smoothing, and precautionary saving in urban China. Journal of Comparative Economics, 31(3), 465-485. doi:10.1016/S0147-5967(03)00069-6.

Qin, D. (2003). Determinants of household savings in China and their role in quasi-money supply. Economics of Transition, 11(3), 513-537. doi:10.1111/1468-0351.00161.

Qin, X., \& Ren, R. (2008). Comparable household saving rates for China and the United States. Review of Income and Wealth, 54(4), 656-670. doi: 10.1111/j.1475-4991.2008.00294.x.

Powell, M., \& Ansic, D. (1997). Gender differences in risk behaviour in financial decision-making: An experimental analysis. Journal of Economic Psychology, 18(6), 605-628. doi:10.1016/S01674870(97)00026-3.

Robb, C. A., Babiarz, P., \& Woodyard, A. (2012). The demand for financial professionals' advice: The role of financial knowledge, satisfaction, and confidence. Financial Services Review, 21(4), 291305 .

Robb, C. A., \& Woodyard, A. S. (2011). Financial knowledge and 'best practice' behavior. Journal of Financial Counseling and Planning, 22(1), 36-46.

Sharpe, D. L., Yao, R., \& Liao, L. (2012). Correlates of credit card adoption in urban China. Journal of Family and Economic Issues, 33(2), 156-166. doi: 10.1007/s10834-012-9309-0. 
Shefrin, H. M., \& Thaler, R. H. (1988). The behavioral life-cycle hypothesis.Economic inquiry, 26(4), 609-643.

Sundén, A. E., \& Surette, B. J. (1998). Gender differences in the allocation of assets in retirement savings plans. American Economic Review, 88(2), 207-211. Stable URL: http://www.jstor.org/stable/116920.

Tam, O. K. (Ed.). (2013). Financial Reform in China. New York, NY: Routledge.

Van Rooij, M., Lusardi, A., \& Alessie, R. (2011). Financial literacy and stock market participation. Journal of Financial Economics, 101(2), 449-472. doi:10.1016/j.jfineco.2011.03.006.

Wang, C., \& Tian, C. (2012). Stock market participation, participation rate and determinants. Economic Research Journal, 10, 97-107. [in Chinese]

Xiao, J. J., Tang, C., Serido, J., \& Shim, S. (2011). Antecedents and consequences of risky credit behavior among college students: Application and extension of the theory of planned behavior. Journal of Public Policy and Marketing, 30(2), 239-245. doi:10.1509/jppm.30.2.239.

Xu, Y., Beller, A. H., Roberts, B. W., \& Brown, J. R. (2015). Personality and Financial Outcomes. Working paper, University of Illinois.

Zhao, C. (2012, April). Development of Chinese government bonds in the secondary market, issues and policy recommendations. China Bond. 19-23. [in Chinese] 
TABLE 1

Relationship Between Financial Planning and Investment Decisions for Chinese Urban Households (2008 SCCFIE, N=2,079)

\begin{tabular}{|c|c|c|c|c|c|c|c|}
\hline \multirow[b]{2}{*}{ Investments decisions } & \multirow[b]{2}{*}{$\begin{array}{c}\text { All } \\
\text { Households }\end{array}$} & \multicolumn{2}{|c|}{$\begin{array}{l}\text { Has a long-term financial } \\
\text { plan }\end{array}$} & \multicolumn{2}{|c|}{$\begin{array}{l}\text { Has at least some understanding } \\
\text { of financial planning methods } \\
\text { currently available }\end{array}$} & \multicolumn{2}{|c|}{$\begin{array}{l}\text { Has at least some understanding } \\
\text { of risk and return associated } \\
\text { with various financial products }\end{array}$} \\
\hline & & Yes $=1$ & $\mathrm{No}=0$ & Yes $=1$ & $\mathrm{No}=0$ & Yes $=1$ & $\mathrm{No}=0$ \\
\hline \multirow{2}{*}{$\begin{array}{l}\text { No stocks, mutual funds, } \\
\text { or government bonds }\end{array}$} & $67.7 \%$ & $45.5 \%$ & $54.5 \%$ & $53.2 \%$ & $46.8 \%$ & $32.6 \%$ & $67.4 \%$ \\
\hline & (1407) & $(640)$ & $(767)$ & (749) & $(659)$ & $(459)$ & (949) \\
\hline \multirow[t]{2}{*}{ Stocks only } & $14.0 \%$ & $73.6 \%$ & $25.7 \%$ & $82.1 \%$ & $17.1 \%$ & $86.4 \%$ & $12.9 \%$ \\
\hline & $(291)$ & (214) & $(75)$ & (239) & $(50)$ & $(251)$ & (38) \\
\hline \multirow[t]{2}{*}{ Mutual funds only } & $4.0 \%$ & $70.0 \%$ & $32.5 \%$ & $85.0 \%$ & $15.0 \%$ & $82.5 \%$ & $20.0 \%$ \\
\hline & (83) & (58) & (27) & (71) & (12) & (69) & (17) \\
\hline \multirow[t]{2}{*}{ Government bonds only } & $2.0 \%$ & $80.0 \%$ & $20.0 \%$ & $80.0 \%$ & $20.0 \%$ & $60.0 \%$ & $40.0 \%$ \\
\hline & $(42)$ & (33) & (8) & (33) & (8) & $(25)$ & (17) \\
\hline \multirow[t]{2}{*}{ Stocks \& mutual funds } & $6.5 \%$ & $83.1 \%$ & $16.9 \%$ & $89.2 \%$ & $9.2 \%$ & $89.2 \%$ & $9.2 \%$ \\
\hline & (135) & $(112)$ & (23) & $(121)$ & (12) & $(121)$ & (12) \\
\hline \multirow[t]{2}{*}{ Stocks \& government bonds } & $1.1 \%$ & $90.9 \%$ & $9.1 \%$ & $100.0 \%$ & $0.0 \%$ & $81.8 \%$ & $9.1 \%$ \\
\hline & $(23)$ & $(21)$ & (2) & $(23)$ & $(0)$ & (19) & (2) \\
\hline \multirow[t]{2}{*}{ Mutual funds \& government bonds } & $1.2 \%$ & $91.7 \%$ & $8.3 \%$ & $83.3 \%$ & $8.3 \%$ & $58.3 \%$ & $41.7 \%$ \\
\hline & $(25)$ & (23) & (2) & $(21)$ & (2) & $(15)$ & (10) \\
\hline Stocks, mutual funds, \& & $3.7 \%$ & $78.4 \%$ & $18.9 \%$ & $86.5 \%$ & $13.5 \%$ & $91.9 \%$ & $8.1 \%$ \\
\hline government bonds & (77) & $(60)$ & $(15)$ & $(67)$ & (10) & $(71)$ & (6) \\
\hline Totals & $100.0 \%$ & $55.9 \%$ & $44.1 \%$ & $63.7 \%$ & $36.3 \%$ & $49.4 \%$ & $50.6 \%$ \\
\hline
\end{tabular}

Note: Percentages may not sum to exactly $100 \%$ due to rounding. 
TABLE 2

Descriptive Profile of Chinese Urban Households by Security Holdings and Investment Decisions (2008 SCCFIE, N=2,079)

\begin{tabular}{|c|c|c|c|c|c|c|c|c|c|}
\hline \multirow[b]{3}{*}{ Mean Percentages (\%) } & \multirow{3}{*}{$\begin{array}{c}\text { All } \\
\text { Households } \\
(\mathrm{N}=2,079)\end{array}$} & \multirow{2}{*}{\multicolumn{2}{|c|}{ Holds Securities }} & \multicolumn{6}{|c|}{ Securities } \\
\hline & & & & \multicolumn{2}{|c|}{ Stocks } & \multicolumn{2}{|c|}{ Mutual Funds } & \multicolumn{2}{|c|}{ Government Bonds } \\
\hline & & $\begin{array}{l}\text { Yes=1 } \\
(n=672)\end{array}$ & $\begin{array}{c}\mathrm{No}=0 \\
(\mathrm{n}=1,407)\end{array}$ & $\begin{array}{l}\text { Yes }=1 \\
(n=522)\end{array}$ & $\begin{array}{c}\mathrm{No}=0 \\
(\mathrm{n}=1,557)\end{array}$ & $\begin{array}{l}\text { Yes=1 } \\
(n=319)\end{array}$ & $\begin{array}{c}\mathrm{No}=0 \\
(\mathrm{n}=1,760)\end{array}$ & $\begin{array}{l}\text { Yes=1 } \\
(n=167)\end{array}$ & $\begin{array}{c}\mathrm{No}=0 \\
(\mathrm{n}=1,912)\end{array}$ \\
\hline All households & 100.0 & 32.3 & 67.7 & 25.1 & 74.9 & 15.4 & 84.6 & 8.0 & 92.0 \\
\hline \multicolumn{10}{|c|}{ Do you have a long-term financial plan? } \\
\hline Yes & 55.9 & 77.8 & 45.5 & 78.4 & 48.4 & 79.6 & 51.7 & 83.2 & 53.6 \\
\hline No & 44.1 & 22.2 & 54.5 & 21.7 & 51.6 & 20.4 & 48.4 & 16.8 & 46.4 \\
\hline \multicolumn{10}{|c|}{ To what extent, do you understand the types of financial planning methods currently available? } \\
\hline At least some understanding & 63.7 & 85.4 & 53.2 & 86.0 & 56.1 & 87.8 & 59.2 & 85.6 & 61.7 \\
\hline No understanding & 36.3 & 14.6 & 46.8 & 14.0 & 43.9 & 12.2 & 40.8 & 14.4 & 38.3 \\
\hline \multicolumn{10}{|c|}{ To what extent, do you understand the risk and return associated with various financial products? } \\
\hline At least some understanding & 49.4 & 84.7 & 32.7 & 88.5 & 36.4 & 85.9 & 42.9 & 77.8 & 47.0 \\
\hline No understanding & 50.6 & 15.3 & 67.4 & 11.5 & 63.6 & 14.1 & 57.1 & 22.2 & 53.0 \\
\hline \multicolumn{10}{|c|}{ Sources for financial planning information } \\
\hline Relatives, friends & 59.2 & 56.3 & 60.6 & 56.1 & 60.2 & 55.5 & 59.9 & 55.7 & 59.5 \\
\hline Radio, TV & 47.7 & 46.6 & 48.2 & 48.7 & 47.3 & 39.8 & 49.1 & 43.7 & 48.0 \\
\hline Newspapers, magazines, books & 45.7 & 48.8 & 44.3 & 49.2 & 44.6 & 45.5 & 45.8 & 55.7 & 44.9 \\
\hline Internet & 37.9 & 54.0 & 30.2 & 57.1 & 31.5 & 53.9 & 35.0 & 45.5 & 37.2 \\
\hline Financial institutions & 33.4 & 48.1 & 26.4 & 48.5 & 28.3 & 51.7 & 30.1 & 50.3 & 31.9 \\
\hline \multicolumn{10}{|l|}{ Household income (after tax) } \\
\hline 1st quartile & 37.4 & 15.5 & 47.9 & 11.7 & 46.1 & 15.4 & 41.4 & 13.8 & 39.5 \\
\hline 2nd quartile & 15.0 & 10.3 & 17.3 & 9.4 & 16.9 & 9.4 & 16.0 & 6.6 & 15.7 \\
\hline
\end{tabular}




\begin{tabular}{|c|c|c|c|c|c|c|c|c|c|}
\hline 3rd quartile & 23.1 & 27.2 & 21.1 & 27.4 & 21.6 & 22.3 & 23.2 & 22.8 & 23.1 \\
\hline 4th quartile & 24.5 & 47.0 & 13.7 & 51.5 & 15.4 & 53.0 & 19.3 & 56.9 & 21.7 \\
\hline \multicolumn{10}{|c|}{ Wealth (value of residential property) } \\
\hline None & 15.0 & 9.5 & 17.6 & 8.4 & 17.2 & 9.1 & 16.0 & 9.6 & 15.4 \\
\hline$<¥ 100,000$ & 17.3 & 9.8 & 20.9 & 9.4 & 19.9 & 8.8 & 18.9 & 6.0 & 18.4 \\
\hline$¥ 100,000-¥ 500,000$ & 50.3 & 47.6 & 51.6 & 44.4 & 52.3 & 47.3 & 50.9 & 40.1 & 51.2 \\
\hline$>¥ 500,000$ & 17.4 & 33.1 & 9.9 & 37.7 & 10.6 & 34.8 & 14.3 & 44.3 & 15.0 \\
\hline \multicolumn{10}{|l|}{ Education } \\
\hline Less than high school & 18.6 & 6.7 & 24.3 & 4.8 & 23.3 & 4.7 & 21.1 & 9.0 & 19.5 \\
\hline High school diploma & 43.8 & 40.8 & 45.2 & 39.5 & 45.2 & 41.4 & 44.2 & 37.1 & 44.4 \\
\hline Some college or more & 37.6 & 52.5 & 30.5 & 55.8 & 31.5 & 53.9 & 34.7 & 53.9 & 36.2 \\
\hline \multicolumn{10}{|l|}{ Other demographics } \\
\hline Age $(<35)$ & 18.3 & 13.6 & 20.4 & 12.8 & 20.0 & 15.7 & 18.8 & 9.0 & 19.1 \\
\hline Age (35-40) & 28.8 & 35.0 & 26.0 & 38.2 & 25.9 & 35.9 & 27.6 & 26.2 & 29.1 \\
\hline Age (41-50) & 32.1 & 33.3 & 31.6 & 33.5 & 31.7 & 32.3 & 32.1 & 34.4 & 31.9 \\
\hline Age $(>50)$ & 20.8 & 18.1 & 22.0 & 15.5 & 22.4 & 16.1 & 21.6 & 30.3 & 19.9 \\
\hline Female & 55.1 & 51.8 & 56.7 & 50.8 & 56.6 & 53.9 & 55.3 & 55.7 & 55.1 \\
\hline Male & 44.9 & 48.2 & 43.3 & 49.2 & 43.4 & 46.1 & 44.7 & 44.3 & 44.9 \\
\hline Married & 77.2 & 80.1 & 75.8 & 81.0 & 75.9 & 77.7 & 77.1 & 82.6 & 76.7 \\
\hline Not married & 22.8 & 19.9 & 24.2 & 19.0 & 24.1 & 22.3 & 22.9 & 17.4 & 23.3 \\
\hline
\end{tabular}

Note: Percentages may not sum to exactly $100 \%$ due to rounding. Dollar values are expressed in terms of the Chinese Yuan (¥). 
TABLE 3

Logistic Results on Security Holdings and Investment Decisions for Chinese Urban Households (2008 SCCFIE, N=2,079)

\begin{tabular}{|c|c|c|c|c|c|c|c|c|}
\hline \multirow[b]{3}{*}{ Independent Variables } & \multirow{2}{*}{\multicolumn{2}{|c|}{ Holds Securities }} & \multicolumn{6}{|c|}{ Securities } \\
\hline & & & \multicolumn{2}{|c|}{ Stocks } & \multicolumn{2}{|c|}{ Mutual Funds } & \multicolumn{2}{|c|}{ Government Bonds } \\
\hline & Coefficient & $\begin{array}{l}\text { Odds } \\
\text { Ratio }\end{array}$ & Coefficient & $\begin{array}{l}\text { Odds } \\
\text { Ratio }\end{array}$ & Coefficient & $\begin{array}{l}\text { Odds } \\
\text { Ratio }\end{array}$ & Coefficient & $\begin{array}{l}\text { Odds } \\
\text { Ratio }\end{array}$ \\
\hline \multicolumn{9}{|l|}{ Financial planning practices } \\
\hline Has a long-term financial plan & $0.8404 * * *$ & 2.317 & $0.7018^{* * *}$ & 2.017 & $0.6497 * * *$ & 1.915 & $0.9476^{* * *}$ & 2.579 \\
\hline \multicolumn{9}{|l|}{ Has understanding of financial planning } \\
\hline methods currently available & $0.3453 *$ & 1.412 & 0.1747 & 1.191 & $0.4909 *$ & 1.634 & 0.2995 & 1.349 \\
\hline \multicolumn{9}{|l|}{ Has understanding of risk and return } \\
\hline associated $\mathrm{w} /$ various financial products & $1.8819 * * *$ & 6.566 & $2.0248 * * *$ & 7.574 & $1.5077 * * *$ & 4.516 & $0.5901 *$ & 1.804 \\
\hline \multicolumn{9}{|l|}{ Sources for financial planning information } \\
\hline Relatives, friends & -0.1642 & 0.849 & -0.0853 & 0.918 & -0.1940 & 0.824 & -0.0817 & 0.922 \\
\hline Radio, TV & 0.0339 & 1.035 & 0.2288 & 1.257 & $-0.3343 *$ & 0.716 & -0.1281 & 0.880 \\
\hline Newspapers, magazines, books & $-0.2570^{*}$ & 0.773 & -0.2325 & 0.793 & $-0.3354 *$ & 0.715 & 0.2545 & 1.290 \\
\hline Internet & $0.3800 *$ & 1.462 & $0.3920^{*}$ & 1.480 & 0.0536 & 1.055 & -0.1213 & 0.886 \\
\hline Financial institutions & 0.1990 & 1.220 & 0.0722 & 1.075 & 0.1144 & 1.121 & 0.2154 & 1.240 \\
\hline \multicolumn{9}{|l|}{ Household income (after tax) } \\
\hline \multicolumn{9}{|l|}{$I^{s t}$ quartile (Reference Group) } \\
\hline 2nd quartile & 0.2982 & 1.347 & $0.4689^{*}$ & 1.598 & 0.1001 & 1.105 & -0.1054 & 0.900 \\
\hline 3rd quartile & $0.7220^{* * *}$ & 2.059 & $0.8617 * * *$ & 2.367 & 0.2733 & 1.314 & $0.6339^{*}$ & 1.885 \\
\hline 4th quartile & $1.4466^{* * *}$ & 4.248 & $1.5351 * * *$ & 4.642 & $1.0267 * * *$ & 2.792 & $1.3143 * * *$ & 3.722 \\
\hline \multicolumn{9}{|l|}{ Wealth (value of residential property) } \\
\hline \multicolumn{9}{|l|}{ None (Reference Group) } \\
\hline$<\$ 100,000$ & -0.2009 & 0.818 & -0.0309 & 0.970 & -0.2159 & 0.806 & -0.7304 & 0.482 \\
\hline$\$ 100,000-\$ 500,000$ & 0.0325 & 1.033 & 0.0554 & 1.057 & 0.0978 & 1.103 & -0.3285 & 0.720 \\
\hline
\end{tabular}


Demographics

Less than high school (Reference Group)

High school diploma

$0.5867^{* *} \quad 1.798$

$0.7007^{* *}$

2.015

$0.8615^{* *} \quad 2.367$

0.1670

1.182

At least some college

$0.7409 * * \quad 2.098$

$0.9099 * * * \quad 2.484$

$0.8588^{* *} \quad 2.360$

0.5948

1.813

Age (<35) (Reference Group)

Age (35-40)

Age (41-50)

$0.2577 \quad 1.29$

$0.5670^{* *} \quad 1.763$

$0.2758 \quad 1.318$

$0.3090 \quad 1.362$

$0.2479 \quad 1.281$

Age $(>50)$

$0.8052 * * * \quad 2.237$

0.4643* 1.591

$\begin{array}{llll}0.4084 & 1.504 & 0.8681 * * & 2.382\end{array}$

Female

0.1244

0.408

Married

0.0526

1.054

0.0754

1.504

0.4972

$1.6277^{* * *} \quad 5.092$

Concordance $86.5 \%$

$0.1809 \quad 1.198$

$0.2351-1.265$

$0.2556 \quad 1.291$

$\begin{array}{lll}87.1 \% & 81.8 \% & 82.0 \%\end{array}$

Note: $* * * \mathrm{p}<0.001, * * \mathrm{p}<0.01$, and $* \mathrm{p}<0.05$. Dollar values are expressed in terms of the Chinese Yuan (¥). 